\title{
The loose housing free barn system for intensive dairy production in Japan
}

\author{
Ko Mimura \\ (Department of Animal Husbandry, Faculty of Fisheries and Animal Husbandry, \\ Hiroshima University, Fukuyama, Japan)
}

(Received for Publication on February 19, 1971)

Since about 1960 there have appeared farms keeping cows in loose housing in various districts of Japan. These farmers had introduced a loose housing free barn system into Japan in view of an expectation that the system should be effective in saving of labour, in adapting cows to hot, wet weather in summer, and in providing facilities for intensive dairy production.

Several American researchers upheld the merits of the loose barn against the conventional barn. HeIZER, SmITH \& ZEHNER (1953) reported that cold temperatures in loose barns had little, if any, effect on health of calves, and such injuries as were observed in the stanchion barn (injured teats, swollen hocks, stiffness and lameness) were almost entirely absent in loose barns. ANGUS \& BARR (1955) also summarized in their review, that initial construction costs for loose barns were less than for conventional barns, feed efficiency appears to be about the same in both systems and loose housing saves about $20 \%$ in terms of labour and $30 \%$ in terms of travel.

In general, a loose housing free barn consists of a resting area, feeding area, barn yard and a milking parlour. This typical form which appeared mainly in the northern part of Japan, Hokkaido and Tohoku, had been introduced directly from the United States. In the west and south districts climates are hot in summer and warm in winter, and farmers who make use of smaller lands for dairying in comparison with the farmers in the northern districts have modified the typical form introduced directly from the United States. That is, in their farms cows have been fed in a resting area eqipped with a serial stanchion-stall which can be opened or shut with one handle. These modifications have probably risen from conditions under which farmers have always been discouraged by the shortage of roughage and they have fed cows brewer's grains and the like.

In this country, although there are a few fundamental researches on the merits of this barn system, many prefectural experimental stations of livestock have recently initiated studies on the probabilities of adoption of this system by dairy farmers under the direction of the National Institute of Animal Husbandry (MtmurA, 1965).

During 1963-1965, the author has undertook several investigations and observations to ascertain if the above mentioned modifications are advantageous for farmers in Japan under intensive dairying, and to ascertain the relative merits of the loose housing barn system versus the conventional barn system. 


\section{Investigations regarding the loose housing barns in the Chugoku districts}

The Chugoku districts, especially its southern part (Seto Inland Sea district) is characterized by a warm climate in winter, hot and arid in summer, and dairying scale comparatively small (Fig. 1).

Recently more cows are being kept on a large scale with the co-operation of several farmers, where large numbers have been introduced and the management system has been changed from the conventional barn system to the loose housing barn system. The author has investigated these farms to ascertain the merits of loose barn versus conventional barn housing from the spring of 1964 to the winter of 1966.

The results of investigations are summarized in Table 1 . The loose barns in the farms investigated could be classified into three types from the standpoint of their composition. One is a normal type barn ( $\mathrm{N}$ type) which consists of a resting area, feeding area, barn yard and a milking parlour. A second is the modified type barn ( $M_{1}$ type) which consists of a

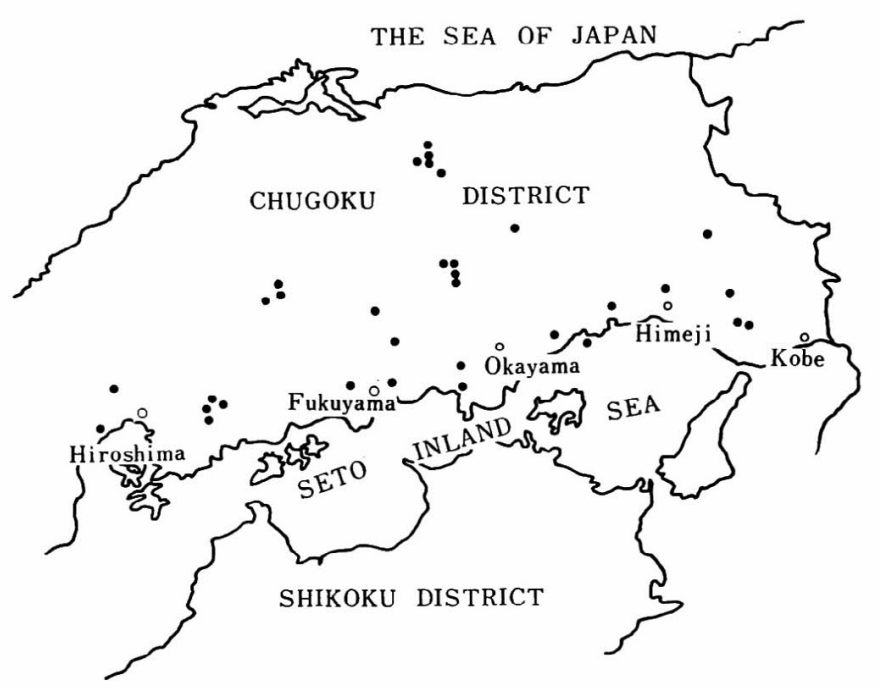

Fig. 1. Farms investigated in the Chugoku districts of Japan

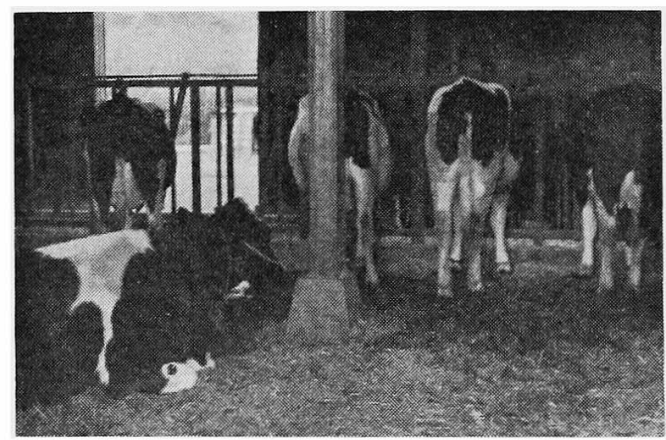

Fig. 2. Resting area with stanchion stall for feeding in modified loose housing free barn of Japan ( $M_{1}$ type barn) 
Loose housing for intensive dairy production

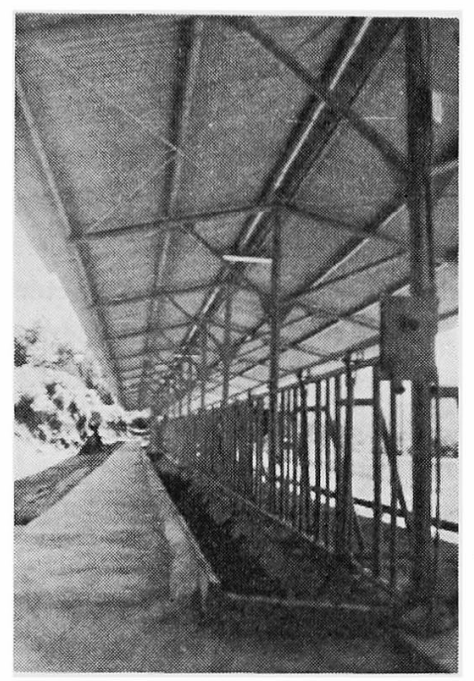

Fig. 3. Feeding area with stanchion stall in modified loose housing free barn of Japan ( $\mathrm{M}_{2}$ type barn)

Table 1. Results of investigations on the farms in Chugoku districts which have introduced the loose housing free barn system

\begin{tabular}{|c|c|c|c|c|c|c|c|c|c|}
\hline Farms & $\begin{array}{l}\text { Locality } \\
\text { (prefec- } \\
\text { ture) }\end{array}$ & $\begin{array}{l}\text { Barn } \\
\text { type }\end{array}$ & $\begin{array}{c}\text { Grazing } \\
\text { type }\end{array}$ & $\begin{array}{l}\text { Nos. of } \\
\text { cows and } \\
\text { heifers }\end{array}$ & $\begin{array}{l}\text { Forage } \\
\text { crop } \\
\text { field } \\
\text { (ha) }\end{array}$ & $\begin{array}{c}\text { Pasture } \\
\text { (ha) }\end{array}$ & $\begin{array}{l}\text { Nos. of } \\
\text { service } \\
\text { per } \\
\text { conception }\end{array}$ & $\begin{array}{l}\text { Calving } \\
\text { intervals } \\
\text { (months) }\end{array}$ & $\begin{array}{l}\text { Milking yield } \\
\text { during 1964- } \\
1965 \text { (daily, } \\
\text { byre average, } \\
\mathrm{kg} \text { ) }\end{array}$ \\
\hline No. 1 & Hiroshima & $\mathrm{N}$ & $\mathrm{G}_{1}$ & 19 & 9.3 & 4.0 & 2.19 & 14.1 & 13.19 \\
\hline No. 2 & $\prime \prime$ & $\mathrm{M}_{1}$ & Zero & 10 & 6.8 & 0.6 & 1.73 & 13.4 & 9.04 \\
\hline No. 3 & $" \prime$ & $\mathrm{M}_{1}$ & Zero & 14 & 3.8 & 0.0 & 2.61 & 13.3 & 11.09 \\
\hline No. 4 & $\prime \prime$ & $\mathrm{M}_{2}$ & Zero & 33 & 13.5 & 0.0 & - & 14.8 & 12.13 \\
\hline No. 5 & $\prime \prime$ & $\mathrm{M}_{1}$ & Zero & 22 & 4.0 & 0.5 & 2.31 & 15.0 & 10.00 \\
\hline No. 6 & Okayama & $\mathrm{M}_{2}$ & Zero & 34 & 7.8 & 1.1 & 2.08 & 13.3 & 10.25 \\
\hline No. 7 & $\prime \prime$ & $\mathrm{M}_{1}$ & $\mathrm{G}_{1}$ & 35 & 1.5 & 19.2 & 1.96 & 12.5 & 12.69 \\
\hline No. 8 & Hyogo & $\mathrm{M}_{1}$ & Zero & 19 & 1.0 & 4.5 & 2.00 & 13.2 & 12.55 \\
\hline No. 9 & $\prime \prime$ & $\mathrm{N}$ & Zero & 24 & 8.0 & 1.0 & - & 17.2 & 9.90 \\
\hline No.10 & $\prime \prime$ & $\mathrm{M}_{1}$ & $\mathrm{G}_{2}$ & 19 & 3.0 & 3.0 & 2.52 & 14.6 & 10.39 \\
\hline
\end{tabular}

Remarks: 1. N: Normal type barn having a resting area, feeding area, barnyard and a milking parlour

$\mathrm{M}_{1}$ : Modified type barn having a resting area with stanchion stall for feeding, barn yard and a milking parlour

$\mathrm{M}_{2}$ : Modified type barn having a feeding area, barn yard, milking parlour and no resting area 2. G1: Keeping cows mainly on grazing during grazing season

$\mathrm{G}_{2}$ : Keeping cows on soiling crops with grazing during grazing season Zero: Zero grazing

resting area with a stanchion stall for feeding, barn yard and a milking parlour, and a third is also the modified type barn $\left(\mathrm{M}_{2}\right.$ type) which consists of a feeding area, barn yard, a milking parlour but no resting area (Fig. 2,3). As noted in Table 1 and by other unpublished data, there are a very few farms where a normal type barn is employed.

These farms are also classified into the following three types from the standpoint of the keeping system during grazing season, i.e. the grazing type ( $G_{1}$ type) in which cows are 
kept mainly on grazing, another grazing type $\left(\mathrm{G}_{2}\right.$ type) in which cows are kept on soiling crops with grazing, and the zero grazing type (Zero type) in which the cows are kept in a loose housing barn during the entire year.

There were a few farms classified as $G_{1}$ or $G_{2}$ types, and it was interesting to find that most of the farms employ a modified type barn and feed the cows soiling crops and by-products from breweries or starch factories. It is clear that the loose housing barn system for intensive dairy production in the southern districts is generally characterized by zero grazing and utilization of by-products. Modified barns and zero grazing originated for a similar reason, namely, individual tethering in a stall is more suitable for the feeding of low roughage-high concent. rate as rations.

The author accepts these modifications as reasonable, because Japanese dairy farmers are always striving for ways and means to get more milk.

Results of observations on productivities and breeding of cows kept in a loose housing free barn are shown in Table 1. There were a few differences in the average number of services per conception, calving intervals and daily milk yield, although these were superior to the average in Japan.

Investigations to clarify these problems were conducted with ten loose housed cows in the Hiroshima University Farm, in which the data were compared with that of the same cows before they were moved into a loose barn (Table 2). The calving intervals were longer and conception rates were lower in loose housed cows than in the cows under conventional management. This was considered to be due to the fact that the loose housed cows had received less individual attention. Since cows are not lined up in an orderly fashion in loose housing, grooming will be more difficult. However, heat periods will be more easily detected in loose housing (Wisconsin Project, 1948; BoYd \& Clark, 1951; KalbFleisch et al., 1952).

When, where and how should cows be carefully observed in loose housing barns? These questions are the most important things to be solved, because average milk yield will be lowered by extension of calving intervals and dairy economics in Japan dictates that maximum milk production must be achieved. Although there was a general extension of calving intervals, milk yields of individual cows in loose barn were a little greater than in the conventional barn. This may be attributed to better feeding, because loose housed cows have more ready access to feeds than cows in conventional barn. In the other experiments (unpublished) milk production decreased when loose housed cows were kept in stalls. From this fact and the behavioural pattern of cows described afterwards, it would be said that cows are healthier and more comfortable in a loose housing than in a conventional barn.

Table 2. Breeding records of cows kept in different barn systems

\begin{tabular}{lccccc}
\hline & Nos. of cows & $\begin{array}{c}\text { Service per } \\
\text { conception }\end{array}$ & $\begin{array}{c}\text { Calving inter- } \\
\text { val (months) }\end{array}$ & $\begin{array}{c}\text { Milk yield, } \\
\text { daily (kg) }\end{array}$ & $\begin{array}{c}\text { Calving } \\
\text { number }\end{array}$ \\
\hline In Conventional barn & 10 & 1.4 & 13.1 & $\begin{array}{c}12.8 \\
(13.1)\end{array}$ & 3 \\
In Loose barn & 10 & 2.4 & 14.1 & 15.2 & 5 \\
Average in Japan & - & - & 15.0 & 13.8 & \\
\hline
\end{tabular}

Remarks: 1. Parenthesized figures are corrected by calving number

2. Investigations performed on cows that had been kept in a conventional barn prior to moving into a loose barn in Hiroshima University Farm

3. Figures of average in Japan are from data of the Ministry of Agr. \& Forestry 


\section{Behavioural pattern of loose housed cows}

During 1963-1965, the author investigated the behaviour of cows kept in the loose barn at the Hiroshima University Farm in order to make comparisons with that of grazing cows and improve the system of loose housing under conditions prevaling in Japan.

Four cows were investigated throughout the season. These were ranked in "hook order" or number of attacks with horns against other cows as follows-B, A, C, D.

Observations had been carried out by the same members of the author's laboratory at about monthly intervals from May 1964 to April 1965. The observation technique used was that described by CHAMBERS (1959), in which activities of individuals under herd management were recorded at 4 minute intervals throughout twenty-four hours and were classified as eating, drinking, ruminating, resting on standing, resting on lying down, idling and milking. The study of the cows was conducted at the same time by the same members. The cows were milked regularly in a milking parlour at $5: 30 \mathrm{a} . \mathrm{m}$. and $4: 30 \mathrm{p.m}$. from spring to autumn, and at $6: 00$ a.m. and $4: 30 \mathrm{p} . \mathrm{m}$. in winter.

From the data obtained in 10 observations, behaviours of cows in each season have been summarized in Table 3. Although eating time gradually declined from late spring toward summer and was lowest in midsummer, there were few differences within seasons except for the summer. NODA (1965) pointed out from his observation on the feeding behaviour of loose housed cows that eating time would be influenced by the water contents of the roughage. HAFEZ \& ScHeIN (1962) also suggested that the pattern of feeding varied according to the physical consistency of the ration.

When loose housed cows are fed with soiling crops, silage, hay etc. it would be better to estimate the amount of feed by ruminating time, because there are high relationships between dry-matter intake and average ruminating time (HANCOCK, 1953; WARdROP, 1953).

The differences in ruminating time within the seasons are also very few except that the total feed intake in loose housed cows decreases remakably before and after midsummer.

In these observations, the behavioural pattern of loose housed cows is different from that described by Hafez \& Schein (1962), Tribe (1955) and Hancock (1953). For example, Hancock reported that grazing time was significantly shorter in midsummer than either in spring or

Table 3. Minutes spent by cows in loose housing free barn

\begin{tabular}{lcccccc}
\hline Activities & $\begin{array}{c}\text { Spring } \\
\text { (April) }\end{array}$ & $\begin{array}{c}\text { Late spring } \\
\text { (June) }\end{array}$ & $\begin{array}{c}\text { Midsummer } \\
\text { (August) }\end{array}$ & $\begin{array}{c}\text { Early autumn } \\
\text { (September) }\end{array}$ & $\begin{array}{c}\text { Autumn } \\
\text { (October) }\end{array}$ & $\begin{array}{c}\text { Winter } \\
\text { (February) }\end{array}$ \\
\hline Eating & $256-372$ & $276-428$ & $192-320$ & $316-400$ & $268-384$ & $252-368$ \\
& $(326)$ & $(370)$ & $(240)$ & $(332)$ & $(322)$ & $(306)$ \\
Ruminating & $444-584$ & $500-548$ & $408-440$ & $456-528$ & $468-628$ & $424-576$ \\
& $(504)$ & $(525)$ & $(428)$ & $(488)$ & $(529)$ & $(498)$ \\
Drinking & $0-8$ & $0-24$ & $12-28$ & $4-28$ & $4-16$ & $0-8$ \\
Resting & $(4)$ & $(13)$ & $(18)$ & $(20)$ & $(9)$ & $(3)$ \\
Idling & $412-572$ & $360-520$ & $556-728$ & $444-572$ & $380-636$ & $532-608$ \\
& $(501)$ & $(430)$ & $(662)$ & $(504)$ & $(525)$ & $(560)$ \\
Milking & $52-100$ & $32-52$ & $40-76$ & $40-68$ & $20-52$ & $40-72$ \\
& $(80)$ & $(43)$ & $(61)$ & $(60)$ & $(26)$ & $(58)$ \\
& $24-28$ & $16-24$ & $16-28$ & $20-24$ & $24-28$ & $16-24$ \\
& $(25)$ & $(20)$ & $(21)$ & $(24)$ & $(25)$ & $(20)$ \\
\hline
\end{tabular}

Remark: Parenthesized figures are means of 4 cows 
autumn, and the time of grazing and ruminating would be variable with seasonal changes, mainly based on the change in quantity and quality of pasture. Because differences in quantity and quality of feeds taken by loose housed cows had been comparatively smaller than those in pastures, the behavioural pattern of loose housed cows would be largely infuenced by climatic factors. As mentioned above, decrease of eating and ruminating time and increase of resting time under the summer conditions may suggest a severe influence of high temperature on behaviour.

Walking distances of loose housed cows are indicated in Table 4. In winter and spring cows walked about from one feeding area to another and between resting area and feeding area, but in late spring and autumn cows lived mainly in a barn yard throughout the day and moved primarily to seek shades during hot weather. The average distance walked was, therefore, shortest in late spring and longest in spring and winter.

It would also be concluded that loose housed cows kept in zero grazing were allowed to take proper exercise, if time of exercise could be estimated by distances walked. How are walking distances influenced by the area of the barn yard and the distances within each facilities? During January of 1965, several observations were conducted to ascertain the significance of barn yard area. During 6 a.m. -6 p.m. cows were kept in about half the area $\left(600 \mathrm{~m}^{2}\right)$ of the barn yard and were observed in the same way as mentioned above (see Tables 4 and 5 ).

In the smaller barn yard the time spent by cows for eating and ruminating was less and for resting and idling more than that in a normal barn yard, though the differences were few.

The average distance walked by cows kept in the smaller area during a 12 hour period was smaller by about 300 meters than for the normal area. The area of the barn yard does, therefore, have an influence on the walking distances of cows but not on feed intakes, because decreases in the time of eating and ruminating were few and these differences were probably influenced by sudden changes in feeding circumstances. This fact suggests that a smaller area does not limit cows in their behavioural pattern.

Table 4. Walking distance in meter

\begin{tabular}{ccccccc} 
Cows & Spring & Late spring & Midsummer & $\begin{array}{c}\text { Early } \\
\text { autumn }\end{array}$ & Autumn & Winter \\
\hline A & 1458 & 716 & 1001 & 1276 & 708 & 1118 \\
B & 1368 & 984 & 1420 & 938 & 920 & 1418 \\
C & 2416 & 1274 & 1570 & 1202 & 1511 & 2192 \\
D & 2550 & 1534 & 1366 & 1345 & 1744 & 2025 \\
Mean & 1948 & 1127 & 1339 & 1190 & 1221 & 1688 \\
\hline
\end{tabular}

Table 5. Average minutes spent by cows and walking distance in half barn yard area as compared with that in normal barn yard area

\begin{tabular}{|c|c|c|c|c|c|c|c|}
\hline & Eating & $\begin{array}{l}\text { Ruminat- } \\
\text { ing }\end{array}$ & Drinking & Resting & Idling & Milking & $\begin{array}{c}\text { Distances } \\
\text { walked }\end{array}$ \\
\hline Normal barn yard area & 279 & 101 & 2 & 265 & 53 & 20 & $1654 \mathrm{~m}$ \\
\hline Half barn yard area & 254 & 82 & 11 & 280 & 75 & 18 & $1352 \mathrm{~m}$ \\
\hline
\end{tabular}

Remark: Observations conducted during 6 a.m. $\sim 6$ p.m. 
Loose housing for intensive dairy production

Table 6. Resting minutes spent by cows in resting area and paddock

\begin{tabular}{|c|c|c|c|c|c|c|c|c|c|c|c|c|c|}
\hline \multirow{2}{*}{ Places } & \multirow{2}{*}{$\begin{array}{l}\text { Resting and } \\
\text { ruminating } \\
\text { form }\end{array}$} & \multicolumn{2}{|c|}{ Spring } & \multicolumn{2}{|c|}{ Late spring } & \multicolumn{2}{|c|}{ Midsummer } & \multicolumn{2}{|c|}{$\begin{array}{l}\text { Early } \\
\text { autumn }\end{array}$} & \multicolumn{2}{|c|}{ Autumn } & \multicolumn{2}{|c|}{ Winter } \\
\hline & & $\begin{array}{c}\text { Cow } \\
\mathrm{B}\end{array}$ & $\begin{array}{c}\text { Cow } \\
\text { D }\end{array}$ & $\begin{array}{c}\text { Cow } \\
\text { B }\end{array}$ & $\begin{array}{c}\text { Cow } \\
\text { D }\end{array}$ & $\begin{array}{c}\text { Cow } \\
\text { B }\end{array}$ & $\begin{array}{c}\text { Cow } \\
\text { D }\end{array}$ & $\begin{array}{c}\text { Cow } \\
\text { B }\end{array}$ & $\begin{array}{c}\text { Cow } \\
\text { D }\end{array}$ & $\begin{array}{c}\text { Cow } \\
\text { B }\end{array}$ & $\begin{array}{c}\text { Cow } \\
\text { D }\end{array}$ & $\begin{array}{c}\text { Cow } \\
\text { B }\end{array}$ & $\begin{array}{c}\text { Cow } \\
\text { D }\end{array}$ \\
\hline \multirow{4}{*}{ 总 } & Standing & 76 & 64 & 0 & 36 & 4 & 76 & 0 & 0 & 0 & 0 & 8 & 16 \\
\hline & Lying & 204 & 0 & 96 & 84 & 0 & 84 & 0 & 0 & 0 & 0 & 0 & 0 \\
\hline & Stan & 8 & 0 & 16 & 0 & 8 & 0 & 104 & 0 & 28 & 48 & 216 & 0 \\
\hline & Lying & 312 & 0 & 696 & 0 & 0 & 0 & 56 & 0 & 544 & 112 & 472 & 0 \\
\hline \multirow{4}{*}{ 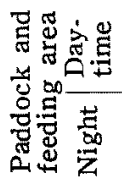 } & Standing & 260 & 344 & 236 & 264 & 392 & 368 & 380 & 368 & 424 & 408 & 168 & 272 \\
\hline & Lying & 204 & 36 & 252 & 88 & 172 & 36 & 96 & 8 & 16 & 16 & 100 & 56 \\
\hline & Standing & 100 & 204 & 12 & 120 & 136 & 176 & 176 & 156 & 8 & 20 & 24 & 120 \\
\hline & Lying & 516 & 384 & 0 & 248 & 368 & 356 & 312 & 440 & 0 & 456 & 20 & 660 \\
\hline \multirow{2}{*}{ Total } & Standing & 444 & 612 & 264 & 420 & 540 & 620 & 660 & 524 & 460 & 476 & 416 & 408 \\
\hline & Lying & 1236 & 420 & 1044 & 420 & 540 & 476 & 464 & 448 & 560 & 584 & 492 & 716 \\
\hline
\end{tabular}

Remark: Cow B is the highest ranking in hook order, and Cow D is the lowest

In Table 4, cows $B$ and $A$ walked less than cows $D$ and $C$. As mentioned above, $B$ was the highest hook order, while $\mathrm{D}$ was the lowest followed by $\mathrm{A}$. B had not disturbed the feeding activity of $\mathrm{A}$, probably because $\mathrm{A}$ was the elder sister of $\mathrm{B}$. This tends to confirm that boss cow will interfere with cows in lower hook order.

The author also observed the activities of resting and ruminating of cows during both the day and night. The results are shown in Table 6 . As the boss cow could occupy her place for resting without restraint, she mainly occupied the resting area at night from winter to spring and the barn yard in summer. Although there was adequate space in the resting area to lie down, D remained primarily in the barn yard throughout the year. This suggests that in warm districts of Japan it will be necessary to have the enough barn yard area for resting and for walking, and that modifications of resting area for feeding and for resting will be reasonable under Japanese conditions. From these points of view the modified resting area in Japan has a similar function to that of the free stall barn which has been introduced recently into Japan from the United States (Muenling \& Fryman, 1965).

\section{Problems on saving of labour in loose housing free barn system in Japan}

KaLbFLEISCH et al. (1952) estimated that labour requirements could be reduced to 60 hours per cow per year in loose housing and to 70 hours in conventional barns. From comparisons of labour requirements reported in the literature ANGUS and BARR (1955) concluded that loose housing saves about 20 percent in terms of labour and 30 percent in terms of travel. In Japan the average hours of labour requirements per cow per year is about 330, which is about five times as much as the average in the United States. Japanese researchers have always em. phasized that the merit of loose housing against a conventional barn is the lessening of labour problems.

From the investigations noted in Table 1, the author noted a decrease of labourers for keeping cows as compared with the numbers of labourers needed in the conventional barns in which cows had been kept prior to removal into the new loose barn. These data are indicated 
Table 7. Numbers of labourers in farms investigated as compared with that before keeping cows in loose barn

\begin{tabular}{cccc}
\hline Farms & $\begin{array}{c}\text { Nos. of cows and } \\
\text { heifers kept }\end{array}$ & $\begin{array}{c}\text { Nos. of labourers } \\
\text { keeping cows in } \\
\text { loose barn }\end{array}$ & $\begin{array}{c}\text { Nos. of labourers } \\
\text { keeping cows in } \\
\text { conventional barn }\end{array}$ \\
\hline No. 1 & 19 & 1 & 2 \\
No. 2 & 10 & 0.5 & $1-2$ \\
No. 3 & 14 & 2 & 2 \\
No. 4 & 33 & 2 & $5^{*}$ \\
No. 5 & 22 & 2 & 3 \\
No. 8 & 19 & 3 & $2-3$ \\
No. 10 & 19 & 2 & 3 \\
\hline
\end{tabular}

Remarks:

1.* Before keeping cows in loose barn farmers had kept cows separately in their conventional barn

2. Farms are the same as the farms on Table 1

Table 8. Average time in minutes per cow per day required for chore labours

\begin{tabular}{rlrrrrrr}
\hline Chore & Year & April & May & June & July & August & Sept. \\
\hline Milking & $1961^{*}$ & 30.6 & 30.4 & 31.3 & 31.4 & 31.1 & 34.7 \\
& $1962^{* *}$ & 10.3 & 10.9 & 12.7 & 11.9 & 10.9 & 10.1 \\
Feeding & $1961^{*}$ & 14.8 & 6.4 & 5.5 & 5.8 & 5.1 & 4.7 \\
& $1962^{* *}$ & 2.9 & 3.6 & 4.0 & 3.8 & 3.5 & 3.8 \\
Cleaning & $1961^{*}$ & 7.6 & 2.8 & 3.1 & 3.3 & 2.9 & 2.8 \\
& $1962^{* *}$ & 5.7 & 3.9 & 3.1 & 2.5 & 2.6 & 1.8 \\
\hline
\end{tabular}

Remarks: *30 cows had kept in conventional barn

** 48 cows had kept in loose barn

By courtesy K. Suzuk1, 1967. Modern management in animal building. Asakura Pub. Co. Ltd. Tokyo

Table 9. Milking time required for 10 cows as compared with 20 cows kept in loose barn

\begin{tabular}{clrrrr}
\hline & & \multicolumn{3}{c}{ In loose housing } \\
& & \multicolumn{2}{c}{ 10 cows } & \multicolumn{2}{c}{ cows } \\
\cline { 3 - 6 } & & Total min. $\begin{array}{l}\text { Min./cow/ } \\
\text { milking }\end{array}$ & Total min. $\begin{array}{l}\text { Min./cow/ } \\
\text { milking }\end{array}$ \\
\hline Variable elements & Milking & 51 & 2.5 & 102 & 2.5 \\
& Feeding of concentrates & 16 & 0.8 & 32 & 0.8 \\
& Drive in (out) & 18 & 0.9 & 36 & 0.9 \\
\hline Invariable elements & Preparation and cleaning & 66 & 3.5 & 66 & 1.7 \\
& Milk treatment & 31 & 1.8 & 31 & 0.8 \\
& Watching & 35 & 1.9 & 35 & 0.9 \\
\hline \multirow{2}{*}{ Total } & & 217 & 10.9 & 302 & 7.6
\end{tabular}

Remark: Total time in variable elements will be changed by milking cows-level, but total time in invariable elements will not be changed

By Courtesy Yoshimoto, T., K. Mimura \& S. Fujil, 1965

in Table 7. But this does not correctly illustrate the merit of loose housing because the farms had not been under the same conditions before and after investigations. The investigations at Oomu Mechanized Farm, locating in the eastern part of Hokkaido, showed that a remarkable saving of labour in milking and in feeding would be possible (Table 8). 
Loose housing for intensive dairy production

Table 10. Average time required for chores (minutes per cow per day)

\begin{tabular}{lcc}
\hline \multicolumn{1}{c}{ Chores } & $\begin{array}{c}\text { Loose barn } \\
(20 \text { cows })\end{array}$ & $\begin{array}{c}\text { Stanchion stall barn } \\
\text { (30 cows) }\end{array}$ \\
\hline Milking & 15.2 & 20.6 \\
Feeding & 5.8 & 5.7 \\
Bedding \& cleaning of barn & 8.5 & 5.0 \\
Handling cows & - & 2.5 \\
The others & 4.3 & 1.2 \\
Total & 33.8 & 35.0 \\
\hline
\end{tabular}

Remarks: 1. Although 13 cows and 7 heifers had been kept in the loose barn, these data are recalculated on 20 cows on the basis of Table 9

2. The others: Miscellaneous jobs

During 1964-1965 the author and his colleagues studied the possibilities of labour saving in the loose housing system. In their report (1965) they suggested that with more than 20 cows, milking time in a loose housing would be cut in half compared with that of 10 cows (Table 9). From the data indicated in Table 10 in which the time required for milking was recalculated on the basis of data in Table 9, a loose barn system has obviously an advantage in saving of labour, although in a conventional barn the cow-level was one and half times as much as that in a loose housing barn (Table 10).

At the same time they reported that dairy chore routes were, on the average, alike in the two systems. Labour requirements were calculated as 100 minutes- $1900 \mathrm{~m}$ per $1000 \mathrm{~m}^{2}$ in the handling of bedding with the cleaning of the barn.

OzAKI (1967) suggested in his survey study that a saving of labour in a loose housing barn was especially greater in milking and feeding than in a conventional barn. From his survey which was not a precise examination, average minutes required for over-all chores in several farms were 13.6 to 15.6 minutes per cow per day with more than 30 cows.

It is very interesting that the saving of labour by Japanese farmers is now approaching the same efficiency as farmers in the United States and England (STurrock, 1949; Boyd \& Clark, 1951; Stewart, 1950 etc.).

\section{Conclusion and summary}

Since about 1960 loose housing has become popular in various districts of Japan for providing better facilities for intensive dairy production. But farmers in Japan especially in the west and south districts, have modified the typical form, although in northern districts there are many farms which had introduced the typical system of loose housing used in the United States.

From the results of several investigations which were conducted on dairy farms distributed in the Chugoku districts during 1964-1965, the author points out that their loose barns are classified into three types, one is the normal type ( $N$ type), another the modified $M_{1}$ type and still another the modified $M_{3}$ type. The $N$ type is characterized by a form of loose barn having a resting area, feeding area, barn yard and a milking parlour. Modified types $\left(\mathrm{M}_{1}, \mathrm{M}_{2}\right)$ are characterized by loose barns consisting of a resting area with stanchion stalls for feeding, a barn yard and milking parlour $\left(M_{1}\right.$ type) or a feeding area, barn yard and milking parlour 
and no resting area $\left(M_{2}\right.$ type). The cows were kept mainly on zero grazing or on soiling crops with grazing.

The author has come to the following conclusions. In the Chugoku districts, loose barns are almost all classified into modified types due to the fact that many cows have to be fed soiling crops and by-products from brewers of starch factories because of the small amount of pasture land.

Also the important problems in the loose housing barn system of heat detection of cows and difficulties in handling cows for breeding remain to be solved.

During 1963-1965 year around observations were made of the behaviour of cows kept in the loose barn at the Hiroshima University Farm. Two other investigations were also conducted in July of 1964 concerning the problem of the area between the barn yard and the resting area.

From the data obtained it can be said that differences in eating and ruminating time during seasons were very small except in midsummer and the total amount of feed intake was remarkably a few in midsummer, probably due to the influences by high temperatures in loose barn. He suggested also that the behavioural pattern of loose housed cows was different from that of cows grazed on pastures where grazing time was variable with changes of season mainly due to the seasonal changes of quantity and quality of pastures.

The walking distances of loose housed cows were a little smaller than that of cows grazed on pastures. The author suggests that walking distance will be influenced by the area of barn yard and distance within each facility.

He also noted that hook order had an effect on distances of walking and the time of using the resting area. These facts indicate that the barn yard should be used for walking and resting together in the warmer districts of Japan.

The author discussed the saving of labour in the loose barn system on basis of their report (1965) and others, and concluded that loose housing had an advantage in milking time and feeding as compared to the conventional barn.

From these data it is concluded that there is a merit in the loose housing system for intensive dairy production in Japan as compared with the conventional barn system, but at the same time it may be necessary to apply certain modifications to the loose housing free barn system.

\section{Acknowledgements}

The author wish acknowledge the assistance of his laboratory staffs, particularly Dr. Y. Asamida, Dr. S. Yamamoto, Mr. T. Ito, Mr. T. Yoshimoto and Mr. T. Nomura. This work were supported by grants from the Research Fund of Ministry of Education. Further the author express his gratitude to Dr. Hans PEDerson who was the chairman of the editorial committee of World Review of Animal Production for his correction of manuscript and for his kindful letters on the article.

The outline of the article was presented at the 9th International Congress of Animal Production, Edinburgh 1966, and a note on the behavioural pattern of loose housing cows was reported on the Jap. Jour. Zootech. Sci. Vol. 40 No. 3, 1969. 


\section{References}

ANGUS, R.C. \& W.L. BARR (1959) J. Dairy Sci., 38: 391-406.

Boyd, L.L. \& L.E. Clark (1951) Univ. Agr. Expt. Sta., Prelim. Rpt. Research and Marketing Project 32.

Chambers, D.T. (1959) J. agric. Sci., 53: 417-424.

Dairy Husb. Agric. Eng. Dept. (1949) Univ. of Wis. Mimeo, 1949.

HAfEZ, E.S.E. \& M.W. ScheIN (1962) The behaviour of cattle (The behaviour of domestic animals 1 ed. 247-296. edited by E.S.E. Hafez). Bailliére Tindall \& Cox, London.

Hancock, J. (1950) Emp. J. exp. Agric., 18: 249-263.

Hancock, J. (1953) Anim. Breed. Abstr., 21: 1-13.

Heizer, E.E., Smith, V.R. \& C.E. Zehner (1953) J. Dairy Sci., 36: 281-292.

MimurA, K. (1970) Technology of livestock management 5 ed. 129-132. Yokendo. Tokyo.

Muehling, A.J. \& L.R. Fryman (1965) Univ. Illinois Coll. Agric. Circular 919.

NodA, S. (1965) Annual Rept. of National Institute of Anim. Husbandry 1965: 101-118.

OzAKI, S. (1967) Transactions of Tottori Soc. Agric. Sci., 19: 136-148.

Stewart, R.E. (1950) Mo. Agr. Exp. Sta., Research Bull. 468.

SturRock, F.G. (1949) Univ. of Cambridge, Farm Econ. Branch, Report 32.

Suzurr, K. (1967) Modern management of animal building 1 ed. Asakura Pub. Tokyo.

TRIBE, D.E. (1955) The behaviour of grazing animals. (Progress in the physiology of farm animals 1 ed. 585-602. edited by J. Hammond) Butterworths. London.

Waite, R., W.B. MacDonald \& W. Holmes (1951) J. agric. Sci., 41: 163-173.

WARDRoP, J.C. (1953) Brit. J. anim. Behav., 1: 23-31.

Yoshimoto, T., K. Mimura \& S. Fujll (1965) J. Fac. Fish. Anim. Husb. Hiroshima Univ., 6: 297-311. 


\section{三 村 耕 \\ (広島大学水畜产学部畜産学科)}

集約酪農にお打る開放放し飼い方式

著者は 1963〜1966 年にわたり，わが国における開放 放し飼い牛舎（以下放飼牛含之称する）の諸問題安検討 する目的で調查ならびに実験を行なった。その概要は第 9 回国際畜産学会議（エジンバラ市，1966年）で講演し たがここに報告する。

1. 中国地方に括ける放飼牛舎の調查

1964 1966 年中国地方の 集約酪農場の放飼牛舍定多 数調査した。栖準型のほ加，休息場が給飼場を兼ねる变 形 $\left(\mathrm{M}_{1}\right)$ 型，休息場を設けない变形 $\left(\mathrm{M}_{3}\right)$ 型があり，こ れらは，放牧を行なっている $\mathrm{G}_{1}$ 型，青刘飼料給与老主 とし放牧も行なう $\mathrm{G}_{2}$ 型およびゼ口放牧型のいずれかと それぞれ結合していた。 ゼ口放牧 $-\mathrm{M}_{1}\left(\mathrm{M}_{2}\right)$ 型が最も ふつうの存在であるが，わが国の特に集約的な関東以西 では，その飼料の種類，給与方法加らて十分にその存 在の理由があると認められた。

2. 放飼牛舎に扔ける乳牛の生態

広島大学付属農場乳牛群についてその季節ごとの行動 の変化を，1963〜1965 年にわたり，4 分間隔 24 時間連 続観察法を用いて試験した。 その大要は本誌 40 巻 3 号 に速報したが，盛夏の採食・反忽㭙間の著しい減少と休 息時間の著しい增加，またその他の季節では余り大きな 差異のないことが認められた。このことから，放飼牛舎
の乳牛の行動は放牧牛のそれと異なること，気温などの 直接的影響があることなどが指摘される。この試験で は, 角つき順位が乳牛の行動に影響することも明らかに された。

\section{3. 放飼牛含の棒造々機能}

生態調查の結果, 順位の低い牛は年中運動場老利用 し，順位の高い牛は夏は運動場を，冬は休息場を利用す ることがわかった．休息場の必要性を示す反面，暖地で は運動場が休息場の機能も有することを示すものであ る. 1965 年運動場の面積を縮少して試験した結果は, 乳 牛群の行動型の根本的变化はないが，採食・反燿時間は やや減少し，休息・遊步時間はやや堌加した。 また歩行 距離は隇少した.

4. 放飼牛舎の管理技術と省力管理

前記 1. の調査結果かよび別に付属農場放飼牛舎飞飼 育した前後に打ける成績を比較することから，放飼牛舎 では受胎率・分婏間隔の成績が一般に低下寸ることが指 摘された。群管理技術における個体管理の方法に改善を 要することを示すものであるう。

本研究の結果からも, 放飼牛舍がつなぎ牛含より省力 的であることが琹められたが，なおこれについても論議 した. 